\title{
Shooting Elephants in Zimbabwe: An Intellectual Journey
}

\author{
Ken Simonsen \\ College of Lake County \\ Grayslake, Illinois
}

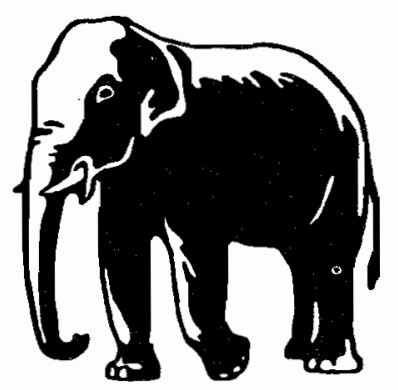

I.

I fired a third time. That was the shot that did for him. You could see the agony of it jolt his whole body and knock the last remnant of strength from his legs. But in falling he seemed for the moment to rise, for as his hind legs collapsed beneath him, he seemed to tower upward like a huge rock toppling, his trunk reaching skyward like a tree. He trumpeted, for the first and only time. And then down he came, his belly toward me, with a crash that seemed to shake the ground even where I lay.

George Orwell

"Shooting an Elephant"

I went to southern Africa to see the wild elephant. Of course, during my journey there were other matters of concern. But my underlying purpose was to encounter these giants directly, face to face. I was spurred on in this purpose by dismay, by an awareness of the calamitous decline of the elephant in East Africa. In the last few decades, Kenya had lost over 100,000 elephants to poachers (David Western speech). Reports

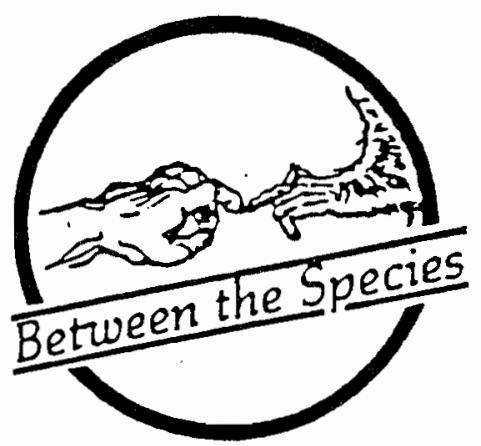

from neighboring countries were equally discouraging. But in southern Africa, and particularly in Zimbabwe, the huge animals still prospered in great numbers. Here, I felt, I could encounter the wild elephant unthreatened by human greed and violence.

But Zimbabwe, I soon discovered, was not a Peaceable Kingdom. Elephants had grown so abundant in past years that their numbers had been reduced by systematic culling. The practice of culling began as early as 1965, when Zimbabwe was still called Southern Rhodesia, and has since become an established practice (Martin and Conybeare 7). This culling process, from my perspective, is as brutal as poaching, although park authorities claim it is done as humanely as possible. In culling elephants, the matriarch is shot first. Elephant families, composed of females and the young of both sexes, are led by older females, on whose accumulated wisdom of waterholes, food sources and incipient dangers the entire family depends. When the matriarch is shot, the family is thrown into confusion, and can be rapidly decimated. Douglas Chadwick, in The Fate of the Elephant, reports that in one incident, three professional hunters were able to kill ninety-eight elephants in one minute (431). Only calves, between one and three years, young enough not to be traumatized by the slaughter of their families, are spared; afterwards they are sold to zoos (Moss 229). One rationale for shooting entire families is that "dead men tell no tales."

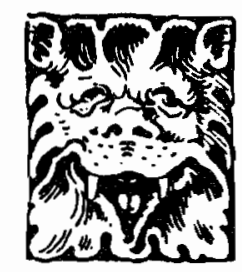

\section{COMMENT}


If there are no survivors, consternation about the slaughter will not spread to the general population of elephants. But even park authorities point out that the recently discovered phenomenon of infrasound undercuts this rationale. Joyce. Payne has discovered that elephants communicate at frequencies lower than the human ear can distinguish, and these frequencies can travel up to six miles (Martin and Conybeare 35). All this suggests that elephants, even those not marked for slaughter, are aware of the process, often come to investigate the killings (Chadwick 432), and avoid waterholes during daylight hours after a culling has taken place there (Martin and Conybeare 35).

There are several reasons put forth for culling in Zimbabwe. R. D. Taylor and D. H. M. Cumming argue that culling elephants must be seen against the "regional background of widespread deforestation and land degradation" (14). The elephants' proclivity for tearing down and devouring trees has brought him into this disrepute. Hwange National Park shows considerable degradation around waterholes. And Zambesi National Park evidences mopane trees with missing tops and downed baobabs, damage attributed to elephants. This damage, it is argued, could very well affect other species dependent on forest habitats, thus adversely affecting biodiversity in the parks (Martin and Conybeare 27).

Another argument in favor of culling is raised by Martin and Conybeare. "The primary reason given here for selecting 'culling' as the option is aesthetic. We wish to see Zimbabwe's national heritage of national (sic) ecosystems within the Parks and Wildlife Estates preserved in the pristine state in which they existed fifteen years ago" $(x)$. The same authors speak of the "alarming loss of mature trees" and the possible decline of "savana and forest species" (5) as a justification for the shooting of elephants, but they state unequivocally that "the matter of elephant culling finally falls under the heading of an aesthetic decision" (3). Again they say, "elephant densities have caused an aesthetically unpleasing loss of woodlands" (27).

There are two arguments being presented here, one ecological and the other aesthetic. I find I have very strong reservations about the second reason. "The scenic qualities of the landscape" (Martin and Conybeare 3) for which elephants were being shot do not seem readily apparent to me. The landscape in Hwange and much of Zambesi National Park consists of scrub woodlands on mostly flattish terrain, and strikes many observers as dull and monotonous. What makes the parks so interesting is not scenery but rather an abundance of animals and birds. On reflection, I concluded that I certainly would not make the journey to Africa to see the mopane or the baobab tree, but I did indeed travel there to see the wild elephant.

At first, the ecological argument seemed to me far more cogent. Since population pressures have forced more and more elephants into confined areas, they are causing great environmental stress because of their excessive numbers. I had in the past accepted the culling of deer in order to preserve suburban forest preserves. Whey then am I so troubled about the shooting of elephants in Zimbabwe? After all, are there not strong parallels here with the Land Ethic of Aldo Leopold? Did not Leopold call for the preservation of the integrity, stability and beauty of the land? (Leopold 262) Weren't the Zimbabwe national park officials merely putting Leopold's ideas in practice? Any doubts I may have had about this parallel to Leopold were dispelled in a conversation with Dr. R. D. Taylor, ecologist for the World Wide Fund for Nature in Harare. Taylor remarked that Aldo Leopold was one of his personal heroes, and that the wildlife management practices in Zimbabwe were consistent with Leopold's principles (Taylor interview).

It was Pascal who said that the heart has reasons the mind knows not of. Perhaps this aphorism was all too appropriate for me. I fully grasped on a cognitive level the cogency of the argument for preserving biodiversity. I clearly understood no animal can prosper if it destroys its own habitat and that of other species. Yet I found I could not resign myself to the idea of culling elephants. It became clear that my trip into Africa was not just a physical journey, nor was it that kind of adventure that expands one's horizons and broadens one's vision of the world. Rather, I began to understand I was on a sort of intellectual journey, in which I was being forced to question some of my fundamental notions about the role of humans in the natural world.

\section{II.}

Intellectual perplexity can be likened to descending darkness, or fog, or stormy weather, or some other apt metaphor. For some, clarity comes in a flash of inspiration. For others, like me, it is more a process of muddling through, of groping one's way towards an impending dawn. Thus it was only gradually, in the midst of my journey into Africa, that I began to 
understand why shooting elephants in Zimbabwe caused me such disquiet.

One cause of my uneasiness, I discovered, is the apparent commercial attitude found in the wildlife management practices in Zimbabwe. Outside of the parks, wild animals are regarded as akin to maize and tobacco; they can be "harvested," "cropped," or "culled" like any commercial commodity. Following this agricultural metaphor, wildlife can be regarded as a sustainable crop; in this way, animals can and should pay their own way. This submerged metaphor informs the praiseworthy CAMPFIRE program, whereby people living in communal lands are given the right to manage wildlife on their lands. By making a small percentage of wild animals available for safari hunting, communal peoples can acquire yearly profits from wealthy hunters willing to spend in excess of $\$ 50,000$ U.S. for the opportunity to shoot trophy animals (Chadwick 440).

But even protected elephants in national parks, when they are culled, can yield profits. Meat, hides and ivory have commercial value. Especially ivory. This was a major reason why Zimbabwe vigorously opposed the CITES agreement of 1989 , by which an overwhelming majority of nations agreed to ban the international ivory trade (Bonner 157). The CITES ban may have saved the East African elephant from extinction, as David Western, head of the Kenya Wildlife Service, claimed in a speech in Harare. But since ivory can no longer be sold on the international market, in Zimbabwe it meant that the elephant is no longer paying his way.

It is not just this commercial attitude toward wildlife that I find disturbing. There is something else even more fundamental underlying this attitude, a presumption about nature that is profoundly anthropocentric. Wildlife has only extrinsic value; it should be used for human benefit. As Taylor and Cumming phrase it, "Wildlife should be used sustainably... in the service of man" (1). Thus the elephant should be used for its meat, hide and ivory. It should be valued for its contribution to tourism "in the service of man." But it does not have intrinsic value; for Taylor and Cumming, it is not valued for its own sake. As the ecohistorian Robert Delort puts it, the elephant in Asia is revered as the god Ganesha, but in Africa it is generally regarded as "a mountain of meat" (69).

And so these thoughts percolated in my consciousness as I finally set out to see the elephants themselves, first at Hwange National Park, where they are overly abundant at waterholes, and then at Zambesi National
Park. At Hwange, in particular, I felt a deep uneasiness. Park officials believe there are simply too many elephants there. I encountered a wide range of estimates, from 22,000 to 40,000 , but the most commonly mentioned estimate is around 35,000 elephants. This is three times greater than what is believed to be the carrying capacity of the park. Culling has not taken place for a few years now, but clearly the pressures for again shooting elephants in Zimbabwe is growing. Rumors abound about cullings that were anticipated and then postponed. Any number of people I spoke with said something must be done about all these elephants. And in the past, that which has been done has been shooting them.

What was it about these creatures that caused me so much concern? When I finally encountered them in the wild, I began to gain some insight into my uneasiness. Perhaps one could call it a kind of recognition, such as some people experience in their encounters with whales and dolphins. I recognized in the wild elephant a fellow creature, an intelligent and curious being whose behavior was not so distant from my own. Like Seneca, I realized that this creature had "a fellowship with the human race." (qtd in Deport 89) I already knew that, like human behavior, much elephant behavior is learned, and this learned behavior reveals a remarkable intelligence. Chadwick gives many instances of elephant intelligence. In one example, he tells of Asian work elephants who were forced to wear a bell in order to reveal their whereabouts after a night of foraging. These clever animals leamed to stuff their bells with mud in order to escape detection and extend their foraging time (289). Cynthia Moss, whose study of the Amboseli elephants spans more than twenty years, records the deep and affectionate bonds that pervade matriarchal families. She describes the elaborate greeting ceremony involving the intertwining of trunks, and records their evident joy when family members are united after even a short separation $(102,105)$. Calves, according to Moss, are regarded with great concern by the females of the family, and are raised in a caring environment. Oddly, elephant family structure bears more evident similarity to the African communal extended family than to the American dysfunctional one. Moss points out a similarity to human feelings, claiming she has seen elephants evidence playfulness, terror and even silliness (65). Chadwick reports that captive elephants have been known to weep under stress (327). Of course some may worry about anthropomorphism 
in this kind of talk about elephants, fearing that human feelings are being read into animal behaviors. But perhaps the only way to fully enter into the life of intelligent and sentient animals is to make the leap, as Moss does, from observable animal behavior to obvious parallels in human experience. Not only must one think like a mountain, as Leopold said, but here, to understand elephant behavior, perhaps one must think like an elephant.

There is one elephant behavior, however, that Moss and other field observers have recorded as being haunting and uncanny. When an elephant dies, other elephants will often remain with it for hours and even days (Moss 278). Often they attempt to bury the dead elephant with branches and debris (Chadwick 121). Sometimes they return to the skeleton of the dead animal and touch the bones and tusks in a lingering manner (Moss 235). What is transpiring in the minds of these giants at these times? Most observers hesitate to offer an explanation. Whatever may be happening, this behavior suggests that elephants are feeling creatures who have some sort of awareness of death.

Given what we know about these intelligent animals, how then can we continue to treat them as commodities, having only extrinsic worth? How can we continue to value them only for their meat, hide, ivory, and capacity to amuse tourists? These elephants are clearly intelligent, feeling creatures. Like humans, they must learn from experience, and in this sense can be said to acquire wisdom. There may be truth in the idea of the wise old elephant. They have a form of communication, inaudible to human ears. They develop strong family bonds, show affection toward one another, and evidence great concern for their young. They even have some sort of an awareness of death. They have in simpler form many of the behaviors we value in humans, and which are often said to give humans intrinsic worth. If humans are valued for their own sakes for these reasons, then on what grounds can intrinsic worth be denied in elephants? They should indeed be valued for their own sakes, not because their bodies can yield carved ivory and elephant foot umbrella stands "in the service of man." These giants have a right, or at least an interest, to live and flourish within the limits of nature.

\section{III.}

What then did I learn from this intellectual journey into Africa? Clearly I came away from Zimbabwe with much anxiety that the shooting of elephants would resume And if it did resume, I believe it would be lamentable, since these giants are, in my estimation, creatures possessing intrinsic worth because they are in so many ways similar to humans. Chadwick, in fact, raises this issue in The Fate of the Elephant. Discussing the similarity of emotions and social relationships between species, he remarks, "If a continuum exists between us and such beings in terms of anatomy, physiology, social behavior and intelligence, it follows that there should be some continuum of moral standards" (475). Of course, it was Peter Singer who argued for such a continuum of moral standards in Animal Liberation, although he did stress sentience rather than intrinsic worth. Nonetheless, if one applies Singer's arguments to elephants rather than to laboratory or factory farm animals, one could argue that elephants deserve to be treated with the same moral consideration we would accord humans who are at comparable mental level (Singer 22). Chadwick points out that the mental level of elephants is comparable to that of these humans when he states that a "surprising number of handlers compared working with elephants to working with mentally handicapped people" (17). We would think it horrendous to cull mentally handicapped humans in order to reduce the pressure of the human species on the natural environment. How then can we justify culling elephants, who are at a comparable mental level? Reflections such as these underscore Cynthia Moss's feelings. She expresses her fears powerfully: "And if the poachers do not come, what of the cullers? I feel sick when I think of a team of marksmen, skinners and butchers moving into Amboseli and slaughtering whole families along with all their knowledge, their traditions, and their memories" (278).

Of course, to those who practice aggressive wildlife management, the answer to this question is patently obvious. The mentally handicapped do not inflict extensive damage on the natural environment, while elephants do. The questions of land degradation and threatened biodiversity, they would reply, still remain unanswered.

Ultimately, I would have to reply that I would prefer to let nature take its course rather than see the shooting of elephants in Zimbabwe resume. Delayed birth, drought, even starvation will doubtless bring the elephant into equilibrium with its habitat. Of course, the price may be high. Elephants might convert much of the forest into savannas, as they have in the past. 
Forest species may decline as grassland species expand. The "loss of entire woodlands and loss of valuable species" may occur, as Martin and Conybeare fear (5). At what point such degradation would occur is, however, unknown. Ecology is a young science, and perhaps not yet adequately developed to predict precisely what would happen if there were no shooting of elephants. Taylor and Cumming claim that "authorities argue that elephants may take systems across thresholds that cannot be recovered... however, neither the threshold nor whether the change is irreversible is known" (14). Moss questions the wisdom of culling, calling it "a drastic, unreasoned step, given our present lack of knowledge of ecosystem dynamics" (271). Western, faced with the overpopulation of elephants in Amboseli, said the choice is to cull or to move, and unequivocally advocated translocation of the giants as an alternative to shooting them (speech).

When elephants and trees come in conflict, authorities disagree radically. And when the final result of shooting elephants is uncertain, when it is a matter of dispute among ecologists, perhaps it is time to avoid violent and aggressive solutions until greater understanding of ecosystems, over time, is achieved. That is to say, perhaps it is better at this time to just let nature be. What I am advocating here is a more modest and less violent attitude toward nature in general and toward elephants in particular. Perhaps it is an act of human hubris to assume that humans know what is best for nature, and perhaps it is an act of arrogance to promote a violent solution when the outcome of one's actions is uncertain and disputable.

The need for modesty and nonviolence was brought home to me on a personal level by my last encounter with the giants. I was on foot, following the shoreline of the Zambesi River, looking for birds, and not even thinking about elephants. Without any warning, I found myself confronting two massive bulls that suddenly emerged in the foliage. Although I was only one hundred paces from these huge creatures, I did not feel I was in any danger, since they regarded me with considerable indifference. Without an elephant gun, without a safari van to escape in, without even enough presence of mind to use my camera, I stood there, defenseless and vulnerable. I realized, confronted by these magnificent animals, that my place in the natural scheme of things was indeed modest. Standing there, I could no longer think anthropocentrically, imagining myself as the renter of nature, with the power of life and death over these creatures. Of course I did admire these giants for their human-like qualities, for their intelligence, their playfulness, their affectionate natures, their evident conscious awareness. But I was beginning to suspect that these characteristics were not uniquely human but rather part of a common inheritance we shared with other members of the animal kingdom. The point was not that they were like us. No, the point was that we were like them.

An anthropocentric perspective had distorted my view of animals in the past. But this intellectual journey into Africa had indeed transformed my view of nature. I was beginning to think ecocentrically, in a nature-centered way. The elephants had taught me on the level of lived experience something I had learned theoretically from Aldo Leopold years ago. I was not the master of nature; rather I was, and should be, a mere citizen.

\section{Works Cited}

Bonner, Raymond. At the Hand of Man: Peril and Hope for Africa's Wildlife. New York: Random House, 1993.

Chadwick, Douglas. The Fate of the Elephant. San Francisco: Sierra Club Books, 1992.

Deport, Robert. The Life and Lore of the Elephant. New York: Abrams, 1992.

Leopold, Aldo. A Sand County Almanac. New York: Ballantine, 1966.

Martin, R. B. and A. M. G. Conybeare. Elephant Management in Zimbabwe. Harare: Department of National Parks and Wildlife Management, 1992.

Moss, Cynthia. Elephant Memories. New York: Ivy Books, 1988.

Singer, Peter. Animal Liberation. New York: Avon Books, 1975.

Taylor, R. D. Personal interview. 11 July 1995.

Taylor, R. D. and D. H. M. Cumming. Elephant Management in Southern Africa. Harare: World Wide Fund for Nature, 1993.

Western, David. Speech. Wildlife Society, Zimbabwe. Annual Meeting. Harare. 14 July 1995.

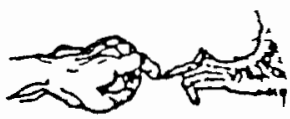

